\title{
The role of arbuscular mycorrhiza in zinc uptake by lettuce grown at two phosphorus levels in the substrate
}

\author{
Anna Konieczny, Iwona Kowalska \\ Unit of Plant Nutrition, Institute of Plant Biology and Biotechnology, Faculty of Biotechnology and Horticulture, University of \\ Agriculture in Kraków, 29 Listopada 54, 31-425 Krakow, Poland \\ e-mail: rokowals@cyf-kr.edu.pl
}

\begin{abstract}
Arbuscular mycorrhizal fungi (AMF) play an important role in $\mathrm{Zn}$ uptake by plants and can partially mitigate the effects of its deficit. On the other hand, they are involved in reducing the accumulation of $\mathrm{Zn}$ and its toxicity to plants when it is present in excessive concentrations in the soil. The aim of the study was to investigate the effect of two AMF, i.e., Funneliformis mosseae and Rhizophagus intraradices on $\mathrm{Zn}$ uptake by lettuce plants grown at two P levels and elevated concentrations of $\mathrm{Zn}$ in a peat substrate. The experiment demonstrated the effectiveness of mycorrhization of lettuce grown in the peat substrate; however, the arbuscular mycorrhiza did not reduce the uptake of $\mathrm{Zn}$ by lettuce. The AMF used in the experiment differentially affected the $\mathrm{Zn}$ content in lettuce. Compared to uninoculated plants, $R$. intraradices increased the $\mathrm{Zn}$ content in lettuce, whereas F. mosseae did not affect the $\mathrm{Zn}$ content.
\end{abstract}

Key words: heavy metal, Funneliformis mosseae, Rhizophagus intraradices, plant nutrition, yield

\section{Introduction}

Arbuscular mycorrhizal fungi (AMF) can form mutualistic relationships with at least $90 \%$ of plant species, including horticultural plants. This symbiosis, which occurs in plant roots, is based on the bidirectional exchange of substances between the fungus and the host plant (Smith and Read 2008). The AMF increase the absorption surface of the roots and the bioavailability of some nutrients, which contributes to enhancing nutrient and water uptake by plants (Karandashov and Bucher 2005, Karagiannidis et al. 2007). Moreover, these fungi stimulate production of hormones that regulate plant growth and plant tolerance to biotic and abiotic stress factors, including an increased concentration of heavy metals in the rhizosphere (Li and Christie 2001, Vincente-Sánchez et al. 2014, Ruiz-Lozano et al. 2016). The effect of AMF in reducing the heavy metal content in plants might be a result of the strong metal-binding capacity of mycorrhizal structures, as well as due to the immobilisation of metal ions in the mycorrhizosphere (Joner et al. 2000, Christie et al. 2004). Furthermore, the increased plant tolerance to stress might be associated with a better plant nutritional status, the enhanced production of phytohormones, as well as an improvement in the structure of the substrate by the fungus, which leads to an improvement in plant growth and development in unfavorable environmental conditions (Turnau et al. 2002, Christie et al. 2004). The metal-binding capacity of AMF might be related to the amount of external mycelia and internal hyphae (Christie et al. 2004), which is influenced by many external factors (Smith and Read 2008). One of these factors is a high concentration of phosphorus $(P)$ in the root zone, which causes a reduction in the development of mycorrhizal structures, which has been demonstrated by many studies (Schmidt et al. 2010, Kowalska et al. 2015).

Because of its physiological function, zinc $(\mathrm{Zn})$ is an essential micronutrient for plant growth and development (Benton Storey 2007). The general values for the average $\mathrm{Zn}$ content in soils all over the world range between 60 and $89 \mathrm{mg} \mathrm{kg}^{-1}$ (Kabata-Pendias 2011). However, $\mathrm{Zn}$ is a component of many waste substances and compounds released into the environment, which might cause its excessive accumulation in the soil, especially in industrialised areas. Increased $\mathrm{Zn}$ concentration in the soil mainly results of the emissions from smelters and incinerators, excessive application of $\mathrm{Zn}$ fertilizers and pesticides, using of contaminated sewage sludge, dispersal of main waste as well as release of $\mathrm{Zn}$ from galvanized wastes (Chaney 1993). Contemporarily observed soil contamination with Zn contributed to its extremely high accumulation in the top layer of soil in certain areas (Kabata-Pendias 2011). The $\mathrm{Zn}$ contents in soil found near mine and industrializes areas reached 180000 in Belgium, 50000 in United States and $13800 \mathrm{mg} \mathrm{kg}^{-1}$ in Poland (Rosen et al. 1978, Scokart et al. 1983, Kabata-Pendias 2011). An excessive concentration of $\mathrm{Zn}$ in the soil leads to an increased concentration of plants, where it affects plant growth and development and thereby reduces the quantity and quality of yield (Chaney 1993). Arbuscular mycorrhizal fungi play an important role in $\mathrm{Zn}$ uptake and can partly mitigate the effects of its deficit (Thompson et al. 2013). Surprisingly, AMF are involved in reducing the accumulation of $\mathrm{Zn}$ and its toxicity to plants in excessive concentrations of this heavy metal in the soil (Li and Christie 2001, Chen et al. 2003). 
Lettuce (Lactuca sativa L.), is a popular vegetable in the human diet, due to its nutritional value and low calorific content (Nicolle et al. 2004). It belongs to the group of leafy vegetables that have the highest ability to accumulate heavy metals (Smical et al. 2008). Therefore, by limiting the uptake and accumulation of Zn, AMF might significantly contribute to improving the nutritional value of this vegetable when it is grown in the presence of a high concentration of this heavy metal in the root zone.

We hypothesized that mycorrhizal colonisation of lettuce roots grown in high Zn concentrations in the substrate reduces the content of $\mathrm{Zn}$ in lettuce and improves its nutritional quality. Therefore, the main objective of this study was to evaluate effect of AMF on Zn uptake by lettuce plants grown in elevated concentrations of this micronutrient in the substrate. We also determined the effect of two $P$ levels in the substrate on the colonisation of lettuce roots with AMF, as well as effect of different $P$ and $Z n$ levels in the substrate, and the effect of colonisation of lettuce roots with AMF on the nutritional status of plants, and on the quantity and quality of the yield.

\section{Material and methods}

\section{Biological material and experimental design}

A $2 \times 3 \times 3$ factorial experiment was conducted in the spring of 2014 and 2015 at the foil tunnel belonging to the University of Agriculture in Krakow. Lettuce plants (Lactuca sativa L.) cv. Melodion (Enza Zaden) were grown in pots filled with peat substrate. The first factor of the experiment included two levels of $P$ in the substrate (70 or $\left.140 \mathrm{mg} \mathrm{dm}^{-3}\right)$, the second consisted of three levels of $\mathrm{Zn}$ in the substrate $\left(20,50\right.$ or $\left.100 \mathrm{mg} \mathrm{dm}^{-3}\right)$ and the third consisted of inoculation of the peat substrate with arbuscular mycorrhizal fungi (-AMF - not inoculated, $+\mathrm{AMF}_{1}$ inoculated with Funneliformis mosseae, $+\mathrm{AMF}_{2}$ - inoculated with Rhizophagus intraradices). The experiment consisted of 18 treatments, each in triplicate and each replication consisted of eight pots.

Untreated lettuce seeds were sown in multipots (DP 42/96, 96 cone-shaped cells, $55 \mathrm{~cm}^{3}$ volume of single cell) filled with peat substrate, limed and supplemented with nutrients to the level recommended for the production of lettuce seedlings. At the time of sowing, some batches of seeds were treated with inoculum containing F. mosseae or $R$. intraradices (SYMBIOM 720 propagules $\mathrm{g}^{-1}$ ), by mixing the inoculum with the substrate. The seedlings were transferred to $2-L$ pots filled with peat substrate when the seedlings had 3-4 fully developed leaves. The peat substrate was prepared using moss peat $\left(\operatorname{Kronen}^{\circledR}\right)$, limed on the basis of a neutralisation curve to $\mathrm{pH} 6.0$. The content of nutrients for all plants, with the exception of $P$ and $Z n$, was supplemented to the same level i.e., (in $m g \mathrm{dm}^{-3}$ ): $\mathrm{N}-180, \mathrm{~K}-220, \mathrm{Mg}-160, \mathrm{Fe}-20, \mathrm{Mn}-20, \mathrm{Cu}-5, \mathrm{~B}-1$, Mo - 1. Plants were divided into two subblocks, which received one of two different concentrations of $\mathrm{P}\left(\mathrm{Ca}\left[\mathrm{H}_{2} \mathrm{PO}_{4}\right]_{2} \mathrm{H}_{2} \mathrm{O}\right)$ : a concentration that was optimal for lettuce - $140 \mathrm{mg} \mathrm{dm}^{-3}$, or a lower concentration of $70 \mathrm{mg} \mathrm{dm}^{-3}$. In each sub-block, three different concentrations of $\mathrm{Zn}\left(\mathrm{ZnSO}_{4} 7 \mathrm{H}_{2} \mathrm{O}\right)$ were applied: 20 (optimal for lettuce), 50 or $100 \mathrm{mg} \mathrm{dm}^{-3}$. Part of the peat substrate within each $\mathrm{Zn}$ concentration was inoculated with F. mosseae or $R$. intraradices (SYMBIOM, 720 propagules $\mathrm{g}^{-1}$ ), at a concentration of $5 \mathrm{~g} \mathrm{dm}^{-3}$ of the substrate. The fertilizers and then the inoculum were separately introduced to the substrate before planting, by mixing with the substrate. Plants were irrigated solely with water throughout the growing season, which was applied by a drip irrigation system. The frequency of irrigation was adjusted to the phase of growth and substrate moisture. The temperature in the tunnel was maintained at $16{ }^{\circ} \mathrm{C}$ on cloudy days, $21{ }^{\circ} \mathrm{C}$ on sunny days and $12{ }^{\circ} \mathrm{C}$ at night. Lettuce plants were harvested once, at the consumption stage (46 days after planting seedlings into the pots) and then the plant material was analysed.

\section{Observation and measurements}

\section{Mycorrhizal colonisation}

The root systems of the lettuce plants were isolated at the end of cultivation from three pots from each replicate. Samples of $10 \mathrm{~g}$ were collected from the isolated root systems and were used to prepare microscope slides according to a modified method of Phillips and Hayman (1970). The collected roots were cold-macerated in $10 \%$ $\mathrm{KOH}(12 \mathrm{~h})$, rinsed with water, acidified with $5 \%$ lactic acid $(12 \mathrm{~h})$ and stained with $0.03 \%$ aniline blue dissolved a the mixture of lactic acid, glycerol and distilled water (v/v/v 1:1:1). The time of maceration and acidification was limited to $12 \mathrm{~h}$ due to the delicate structure of lettuce roots. Microscope slides were prepared from stained roots, cut into $1 \mathrm{~cm}$ pieces and encapsulated in a mixture of glycerol and lactic acid (v/v 5:1), and the slides were observed using an Axio Imager N2 (Carl Zeiss) microscope via Nomarsky optics. Each replication was represented by 90 pieces of root, each having a length of $1 \mathrm{~cm}$. The colonisation of lettuce roots by AMF was assessed accord- 
ing to the method of Trouvelot et al. (1986), by determining the following parameters: mycorrhizal frequency (F), relative mycorrhizal intensity (M), and relative abundance of arbuscules (A). These mycorrhizal parameters were calculated using Mycocalc software (http://www2.dijon.inra.fr/mychintec/Mycocalc-prg/download.html).

\section{Yield}

The yield of lettuce was expressed as the fresh weight of a head. Plants were collected separately from each replication, weighted, counted and the mean weight of a head was calculated for each replicate.

\section{Quality of plants}

At harvest, five representative plants from each replicate were selected for chemical analysis of the plant material. One-quarter of each lettuce head was chopped in a blender. Dry matter, using dryer method $\left(105^{\circ} \mathrm{C}\right)$ and the content of glucose, fructose and sucrose after ethanol extraction by capillary electrophoresis (Beckman Coulter PA 800plus Pharmaceutical Analysis System) using a kit from Analis Scientific Instruments for Laboratories (Belgium) $\left(\mathrm{NaH}_{2} \mathrm{PO}_{4}(36 \mathrm{mmol}), \mathrm{NaOH}(130 \mathrm{mmol}), \beta\right.$ - cyclodextrin, $\left.\mathrm{pH}=12.7\right)$ were determined. A second quarter of each lettuce was cut with a porcelain knife and following extraction with $2 \%$ oxalic acid, the level of ascorbic acid was determined by capillary electrophoresis using a buffer containing: $\mathrm{NaH}_{2} \mathrm{PO}_{4}(30 \mathrm{mmol}), \mathrm{Na}_{2} \mathrm{~B}_{4} \mathrm{O}_{7}(15$ mmol) and CTAB (0.2 mmol), $\mathrm{pH}=8.80$ (Zhao et al. 2011). The remaining half of each lettuce was dried at $65^{\circ} \mathrm{C}$ $(24 \mathrm{~h})$ in a laboratory dryer with forced air circulation. Dried samples were ground in a variable speed rotor mill Pulverisette 14 (FRITSH) using a $0.05 \mathrm{~mm}$ sieve and the content of $\mathrm{P}, \mathrm{K}, \mathrm{Ca}, \mathrm{Mg}, \mathrm{Cu}, \mathrm{Fe}, \mathrm{B}, \mathrm{Mn}, \mathrm{Mo}$ and $\mathrm{Zn}$ was determined, after mineralisation in 65\% extra pure $\mathrm{HNO}_{3}$ in a CEM MARS-5 Xpress microwave system (Pasławski and Migaszewski 2006), using a high-dispersion spectrometer ICP-OES (Inductively Coupled Plasma Optical Emission Spectrometry,Prodigy Teledyne Leeman Labs). The leaf $\mathrm{N}$ content was assayed by the Kjeldahl method using a VELP Scientifica UDK 193 distillation unit (Persson and Wennerholm 1999).

\section{Statistical analysis}

Statistical analyses were performed using STATISTICA 10.PL (StatSoft Inc., USA). A three-way analysis of variance was used to determine the main effects of experimental factors and interactions among main effects. To determine the significance between means, the HSD Tukey test was used. Tests were considered significant at a probability level below $0.05(p<0.05)$. Similar results were obtained in both years of the experiment and are therefore presented as the means of the data in 2014 and 2015.

\section{Results \\ Mycorrhizal colonisation}

The effectiveness of mycorrhization of lettuce with both $\mathrm{AMF}$ i.e., F. mosseae $\left(+\mathrm{AMF}_{1}\right)$ and $R$. intraradices $\left(+\mathrm{AMF}_{2}\right)$ was demonstrated in this experiment. Independently of the other experimental factors, the mycorrhizal frequency (F) in roots of plants inoculated with F. mosseae and R. intraradices was 23.81 and $20.40 \%$, respectively, and the relative mycorrhizal intensity (M) was 0.77 and $1.23 \%$, respectively (Table 1 ). The relative abundance of arbuscules (A) in roots inoculated with $R$. intraradices was significantly higher than in F. mosseae and was 0.18 and $0.01 \%$, respectively. The level of $P$ in the substrate, irrespective of mycorrhiza, affected all the examined mycorrhizal parameters. Higher values of $F, M$ and $A$ were observed in the roots of plants grown in the substrate with a reduced concentration of $\mathrm{P}\left(70 \mathrm{mg} \mathrm{dm}^{-3}\right)$ (Table 1). The roots of uninoculated plants showed no mycorrhizal structures.

\section{Yield}

The yield of lettuce, expressed as the weight of the head was influenced by all three experimental factors (Table 2). Taking the concentration of $\mathrm{P}$ into account, a significantly higher head weight was found at the standard $\mathrm{P}$ concentration, than at the reduced concentration (154.26 and $138.75 \mathrm{~g}$, respectively). Increasing the content of $\mathrm{Zn}$ in the substrate led to a decrease in the lettuce head weight. However, there was no significant difference in the yield between plants grown in the substrate with 50 and $100 \mathrm{mg} \mathrm{Zn.} \mathrm{From} \mathrm{the} \mathrm{two} \mathrm{AMF} \mathrm{used} \mathrm{in} \mathrm{the} \mathrm{experiment,} \mathrm{only}$ F. mosseae affected the lettuce yield. Plants inoculated with this fungus were characterised by a higher weight of head, compared to uninoculated plants and those inoculated with $R$. intraradices. 
Table 1. Effect of the phosphorus (P) and zinc (Zn) level in the peat substrate and inoculation of the peat substrate with arbuscular mycorrhizal fungi on the mycorrhizal frequency (F), relative mycorrhizal intensity (M) and relative abundance of arbuscules (A) in lettuce roots

\begin{tabular}{|c|c|c|c|c|c|}
\hline P mg dm ${ }^{-3}$ & Inoculation & $\mathrm{Zn} \mathrm{mg} \mathrm{dm} \mathrm{m}^{-3}$ & $F(\%)$ & $M(\%)$ & $A(\%)$ \\
\hline \multirow[t]{9}{*}{70} & $-A M F$ & 20 & $0.00 \pm 0.00$ & $0.00 \pm 0.00$ & $0.00 \pm 0.00$ \\
\hline & & 50 & $0.00 \pm 0.00$ & $0.00 \pm 0.00$ & $0.00 \pm 0.00$ \\
\hline & & 100 & $0.00 \pm 0.00$ & $0.00 \pm 0.00$ & $0.00 \pm 0.00$ \\
\hline & $+\mathrm{AMF}_{1}$ & 20 & $37.04 \pm 6.49$ & $9.57 \pm 0.34$ & $0.00 \pm 0.00$ \\
\hline & & 50 & $35.66 \pm 3.51$ & $1.30 \pm 0.81$ & $0.03 \pm 0.03$ \\
\hline & & 100 & $35.18 \pm 2.06$ & $1.37 \pm 0.65$ & $0.01 \pm 0.01$ \\
\hline & $+\mathrm{AMF}_{2}$ & 20 & $29.22 \pm 4.28$ & $2.61 \pm 0.99$ & $0.54 \pm 0.29$ \\
\hline & & 50 & $35.93 \pm 5.45$ & $2.37 \pm 0.65$ & $0.32 \pm 0.15$ \\
\hline & & 100 & $26.01 \pm 3.23$ & $1.47 \pm 0.38$ & $0.20 \pm 0.14$ \\
\hline \multirow[t]{10}{*}{140} & $-A M F$ & 20 & $0.00 \pm 0.00$ & $0.00 \pm 0.00$ & $0.00 \pm 0.00$ \\
\hline & & 50 & $0.00 \pm 0.00$ & $0.00 \pm 0.00$ & $0.00 \pm 0.00$ \\
\hline & & 100 & $0.00 \pm 0.00$ & $0.00 \pm 0.00$ & $0.00 \pm 0.00$ \\
\hline & $+\mathrm{AMF}_{1}$ & 20 & $10.77 \pm 1.33$ & $0.18 \pm 0.06$ & $0.00 \pm 0.00$ \\
\hline & & 50 & $10.56 \pm 1.16$ & $0.45 \pm 0.22$ & $0.01 \pm 0.01$ \\
\hline & & 100 & $13.65 \pm 2.54$ & $0.42 \pm 0.11$ & $0.00 \pm 0.00$ \\
\hline & $+\mathrm{AMF}_{2}$ & 20 & $10.09 \pm 1.95$ & $0.31 \pm 0.08$ & $0.01 \pm 0.01$ \\
\hline & & 50 & $13.02 \pm 1.92$ & $0.49 \pm 0.20$ & $0.00 \pm 0.00$ \\
\hline & & 100 & $8.12 \pm 1.59$ & $0.14 \pm 0.04$ & $0.01 \pm 0.00$ \\
\hline & & & \multicolumn{3}{|c|}{ Main effects } \\
\hline 70 & & & $22.12 \pm 3.29 \mathrm{a}$ & $1.12 \pm 0.24 \mathrm{a}$ & $0.12 \pm 0.05 \mathrm{a}$ \\
\hline 140 & & & $7.36 \pm 1.14 \mathrm{~b}$ & $0.22 \pm 0.05 b$ & $0.00 \pm 0.00 \mathrm{~b}$ \\
\hline$-\mathrm{AMF}$ & & & $0.00 \pm 0.00 \mathrm{a}$ & $0.00 \pm 0.00 \mathrm{a}$ & $0.00 \pm 0.00 \mathrm{a}$ \\
\hline$+\mathrm{AMF}_{1}$ & & & $23.81 \pm 3.18 b$ & $0.77 \pm 0.19 b$ & $0.01 \pm 0.01 \mathrm{a}$ \\
\hline$+\mathrm{AMF}_{2}$ & & & $20.40 \pm 2.80 \mathrm{~b}$ & $1.23 \pm 0.30 \mathrm{~b}$ & $0.18 \pm 0.07 \mathrm{~b}$ \\
\hline 20 & & & $14.52 \pm 3.58$ & $0.68 \pm 0.27$ & $0.09 \pm 0.06$ \\
\hline 50 & & & $15.86 \pm 3.74$ & $0.77 \pm 0.25$ & $0.06 \pm 0.04$ \\
\hline \multirow[t]{2}{*}{100} & & & $13.83 \pm 3.23$ & $0.57 \pm 0.18$ & $0.03 \pm 0.03$ \\
\hline & & & \multicolumn{3}{|c|}{ ANOVA } \\
\hline$P$ & & & $*$ & $*$ & $*$ \\
\hline $\begin{array}{l}\text { Inoculation } \\
\text { (AMF) }\end{array}$ & & & $*$ & $*$ & $*$ \\
\hline $\mathrm{Zn}$ & & & n.s. & n.s. & n.s. \\
\hline $\mathrm{P} \times \mathrm{AMF}$ & & & n.s. & n.s. & * \\
\hline$P \times Z n$ & & & n.s. & n.s. & n.s. \\
\hline $\mathrm{AMF} \times \mathrm{Zn}$ & & & n.s. & n.s. & n.s. \\
\hline$P \times A M F \times Z n$ & & & n.s. & n.s. & n.s. \\
\hline
\end{tabular}

$*=$ means are significantly different; $n$.s. $=$ differences are not significant; $\pm=$ standard error of mean (SEM); $\mathrm{a}, \mathrm{b}=$ means followed by different letters differ at $p<0.05 ;-\mathrm{AMF}=$ uninoculated plants with arbuscular mycorrhizal fungi; $+\mathrm{AMF}_{1}=$ plants inoculated with Funneliformis mosseae; $+\mathrm{AMF}_{2}=$ plants inoculated with Rhizophagus intraradices 
Table 2. Effect of the phosphorus (P) and zinc $(\mathrm{Zn})$ level in the peat substrate and inoculation of the peat substrate with AMF on the yield of lettuce expressed as the weight of a head

\begin{tabular}{|c|c|c|c|}
\hline $\mathrm{P} \mathrm{mg} \mathrm{dm}^{-3}$ & Inoculation & $\mathrm{Zn} \mathrm{mg} \mathrm{dm}{ }^{-3}$ & Yield g \\
\hline \multirow[t]{9}{*}{70} & \multirow[t]{3}{*}{$-\mathrm{AMF}$} & 20 & $135.55 \pm 0.39$ \\
\hline & & 50 & $146.61 \pm 0.85$ \\
\hline & & 100 & $140.89 \pm 2.69$ \\
\hline & \multirow[t]{3}{*}{$+\mathrm{AMF}_{1}$} & 20 & $150.51 \pm 0.27$ \\
\hline & & 50 & $133.25 \pm 2.64$ \\
\hline & & 100 & $139.23 \pm 2.40$ \\
\hline & \multirow{3}{*}{$+\mathrm{AMF}_{2}$} & 20 & $127.26 \pm 0.81$ \\
\hline & & 50 & $134.11 \pm 2.41$ \\
\hline & & 100 & $141.36 \pm 1.61$ \\
\hline \multirow[t]{9}{*}{140} & \multirow[t]{3}{*}{$-A M F$} & 20 & $157.79 \pm 6.11$ \\
\hline & & 50 & $145.12 \pm 3.73$ \\
\hline & & 100 & $145.38 \pm 0.43$ \\
\hline & \multirow[t]{3}{*}{$+\mathrm{AMF}_{1}$} & 20 & $191.40 \pm 2.42$ \\
\hline & & 50 & $156.79 \pm 4.13$ \\
\hline & & 100 & $148.00 \pm 3.09$ \\
\hline & \multirow[t]{3}{*}{$+\mathrm{AMF}_{2}$} & 20 & $155.38 \pm 9.75$ \\
\hline & & 50 & $143.98 \pm 5.06$ \\
\hline & & 100 & $144.52 \pm 4.37$ \\
\hline \multicolumn{4}{|c|}{ Main effects } \\
\hline 70 & & & $138.75 \pm 1.41 \mathrm{a}$ \\
\hline 140 & & & $154.26 \pm 3.10 \mathrm{~b}$ \\
\hline$-\mathrm{AMF}$ & & & $145.22 \pm 1.96 \mathrm{a}$ \\
\hline$+\mathrm{AMF}_{1}$ & & & $153.20 \pm 4.63 \mathrm{~b}$ \\
\hline$+\mathrm{AMF}_{2}$ & & & $141.10 \pm 2.73 \mathrm{a}$ \\
\hline 20 & & & $152.98 \pm 5.20 \mathrm{~b}$ \\
\hline 50 & & & $143.31 \pm 2.26 \mathrm{a}$ \\
\hline 100 & & & $143.23 \pm 1.18 \mathrm{a}$ \\
\hline \multicolumn{4}{|c|}{ ANOVA } \\
\hline$P$ & & & $*$ \\
\hline $\begin{array}{l}\text { Inoculation } \\
\text { (AMF) }\end{array}$ & & & $*$ \\
\hline Zinc (Zn) & & & * \\
\hline $\mathrm{P} \times \mathrm{AMF}$ & & & $*$ \\
\hline$P \times Z n$ & & & $*$ \\
\hline $\mathrm{AMF} \times \mathrm{Zn}$ & & & $*$ \\
\hline$P \times A M F \times Z n$ & & & n.s. \\
\hline
\end{tabular}




\section{Quality of lettuce}

The quality of lettuce was evaluated by the content of dry matter, ascorbic acid, sugars (glucose, fructose, sucrose) as well as that of macro- and micronutrients.

The dry matter content was influenced by the concentration of $P$ in the substrate and inoculation with AMF (Table 3). Regardless of the other experimental factors, plants grown in the substrate with a reduced $\mathrm{P}$ concentration were characterised by a higher dry matter content. The application of $R$. intraradices inoculum decreased the dry matter content in comparison to that of uninoculated plants and those inoculated with F. mosseae.

Only the concentration of $P$ in the substrate affected the content of ascorbic acid, which was higher at $70 \mathrm{mg} \mathrm{dm}^{-3}$ $\mathrm{P}$ than at $140 \mathrm{mg} \mathrm{dm}^{-3} \mathrm{P}$ (Table 3).

Table 3. Effect of the phosphorus $(P)$ and zinc $(Z n)$ level in the peat substrate and inoculation of the peat substrate with AMF on the content of dry matter, ascorbic acid, glucose and fructose in leaves of lettuce

\begin{tabular}{|c|c|c|c|c|c|c|}
\hline \multirow{2}{*}{$\mathrm{P} \mathrm{mg} \mathrm{dm} \mathrm{d}^{-3}$} & \multirow{2}{*}{ Inoculation } & \multirow{2}{*}{ Zn mg dm ${ }^{-3}$} & \multirow{2}{*}{ Dry matter \% } & Ascorbic acid & Glucose & Fructose \\
\hline & & & & \multicolumn{3}{|c|}{ mg $100 \mathrm{~g}^{-1} \mathrm{f} . \mathrm{m}}$. \\
\hline \multirow[t]{9}{*}{70} & \multirow[t]{3}{*}{$-A M F$} & 20 & $7.50 \pm 0.04$ & $13.74 \pm 0.28$ & $505.85 \pm 39.71$ & $615.54 \pm 1.38$ \\
\hline & & 50 & $7.21 \pm 0.16$ & $13.52 \pm 1.73$ & $517.58 \pm 11.87$ & $542.47 \pm 2.99$ \\
\hline & & 100 & $7.09 \pm 0.13$ & $12.66 \pm 0.39$ & $478.19 \pm 23.28$ & $605.59 \pm 1.00$ \\
\hline & \multirow[t]{3}{*}{$+\mathrm{AMF}_{1}$} & 20 & $7.80 \pm 0.32$ & $14.72 \pm 0.58$ & $635.89 \pm 44.31$ & $690.43 \pm 67.74$ \\
\hline & & 50 & $7.84 \pm 0.11$ & $16.04 \pm 0.15$ & $602.94 \pm 83.14$ & $635.57 \pm 17.38$ \\
\hline & & 100 & $7.31 \pm 0.10$ & $14.09 \pm 0.71$ & $491.63 \pm 45.24$ & $543.57 \pm 51.55$ \\
\hline & \multirow[t]{3}{*}{$+\mathrm{AMF}_{2}$} & 20 & $7.17 \pm 0.22$ & $12.33 \pm 0.59$ & $562.08 \pm 2.40$ & $579.82 \pm 44.14$ \\
\hline & & 50 & $6.86 \pm 0.18$ & $13.44 \pm 1.12$ & $529.09 \pm 7.34$ & $659.44 \pm 10.03$ \\
\hline & & 100 & $6.61 \pm 0.20$ & $11.91 \pm 0.73$ & $471.05 \pm 46.22$ & $566.56 \pm 68.16$ \\
\hline \multirow[t]{10}{*}{140} & \multirow[t]{3}{*}{$-\mathrm{AMF}$} & 20 & $6.49 \pm 0.07$ & $11.09 \pm 0.57$ & $518.51 \pm 3.20$ & $537.83 \pm 25.35$ \\
\hline & & 50 & $6.86 \pm 0.13$ & $10.58 \pm 0.29$ & $522.52 \pm 20.40$ & $687.69 \pm 3.98$ \\
\hline & & 100 & $6.75 \pm 0.13$ & $11.40 \pm 2.42$ & $584.48 \pm 13.35$ & $704.26 \pm 27.49$ \\
\hline & \multirow[t]{3}{*}{$+\mathrm{AMF}_{1}$} & 20 & $6.05 \pm 0.08$ & $8.27 \pm 0.88$ & $553.31 \pm 5.03$ & $646.66 \pm 8.37$ \\
\hline & & 50 & $6.55 \pm 0.17$ & $9.17 \pm 0.64$ & $497.46 \pm 21.13$ & $594.41 \pm 17.31$ \\
\hline & & 100 & $6.42 \pm 0.16$ & $11.74 \pm 1.54$ & $557.84 \pm 6.53$ & $554.36 \pm 1.32$ \\
\hline & \multirow[t]{4}{*}{$+\mathrm{AMF}_{2}$} & 20 & $5.94 \pm 0.13$ & $12.77 \pm 0.66$ & $516.06 \pm 4.61$ & $597.50 \pm 3.68$ \\
\hline & & 50 & $6.01 \pm 0.04$ & $9.65 \pm 0.26$ & $520.03 \pm 22.51$ & $594.19 \pm 1.45$ \\
\hline & & 100 & $6.82 \pm 0.23$ & $9.67 \pm 1.12$ & $485.28 \pm 23.68$ & $528.45 \pm 58.42$ \\
\hline & & & \multicolumn{4}{|c|}{ Main effects } \\
\hline 70 & & & $7.27 \pm 0.09 \mathrm{~b}$ & $13.61 \pm 0.33 \mathrm{~b}$ & $532.70 \pm 15.55$ & $604.33 \pm 14.55$ \\
\hline 140 & & & $6.43 \pm 0.08 a$ & $10.48 \pm 0.41 \mathrm{a}$ & $528.42 \pm 7.22$ & $605.04 \pm 13.04$ \\
\hline$-\mathrm{AMF}$ & & & $6.98 \pm 0.09 \mathrm{~b}$ & $12.16 \pm 0.52$ & $521.19 \pm 10.77$ & $615.56 \pm 16.39$ \\
\hline$+\mathrm{AMF}_{1}$ & & & $6.99 \pm 0.18 b$ & $12.34 \pm 0.76$ & $556.56 \pm 19.55$ & $610.83 \pm 17.72$ \\
\hline$+\mathrm{AMF}_{2}$ & & & $6.56 \pm 0.13 \mathrm{a}$ & $11.63 \pm 0.45$ & $513.93 \pm 10.76$ & $587.66 \pm 17.02$ \\
\hline 20 & & & $6.83 \pm 0.18$ & $12.15 \pm 0.55$ & $548.62 \pm 13.58$ & $611.30 \pm 16.76$ \\
\hline 50 & & & $6.89 \pm 0.14$ & $12.06 \pm 0.67$ & $531.65 \pm 15.21$ & $618.96 \pm 12.19$ \\
\hline \multirow[t]{2}{*}{100} & & & $6.83 \pm 0.09$ & $11.91 \pm 0.56$ & $511.41 \pm 14.79$ & $583.80 \pm 20.72$ \\
\hline & & & \multicolumn{4}{|c|}{ ANOVA } \\
\hline$P$ & & & $*$ & $*$ & n.s. & n.s. \\
\hline Inoculation (AMF) & & & $*$ & n.s. & n.s. & n.s. \\
\hline $\mathrm{Zn}$ & & & n.s. & n.s. & n.s. & n.s. \\
\hline $\mathrm{P} \times \mathrm{AMF}$ & & & $*$ & n.s. & n.s. & n.s. \\
\hline$P \times Z n$ & & & * & n.s. & n.s. & n.s. \\
\hline AMF $x \mathrm{Zn}$ & & & n.s. & n.s. & n.s. & n.s. \\
\hline$P \times A M F \times Z n$ & & & n.s. & n.s. & n.s. & n.s. \\
\hline
\end{tabular}

$*$ = means are significantly different, n.s. = differences are not significant; \pm = standard error of mean (SEM); $a, b=$ means followed

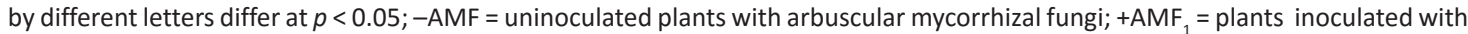
Funneliformis mosseae, $+\mathrm{AMF}_{2}=$ plants inoculated with Rhizophagus intraradices; f.m. = fresh matter 
Among the sugars that were determined in the experiment (glucose, fructose, sucrose), the experimental factors had a significant effect only on the content of sucrose. Significant interactions among all three experimental factors were observed on the content of sucrose (Fig. 1). The level of sucrose in uninoculated plants was slightly influenced by the $\mathrm{P}$ and $\mathrm{Zn}$ concentration in the substrate. The highest contents of sucrose were observed at the highest concentrations of $\mathrm{Zn}$ and $\mathrm{P}$. However, a lower $\mathrm{P}$ concentration caused a marked increase in the accumulation of this sugar in inoculated plants (especially by F. mosseae). No effect of the Zn concentration on the content of sucrose in inoculated plants was observed.

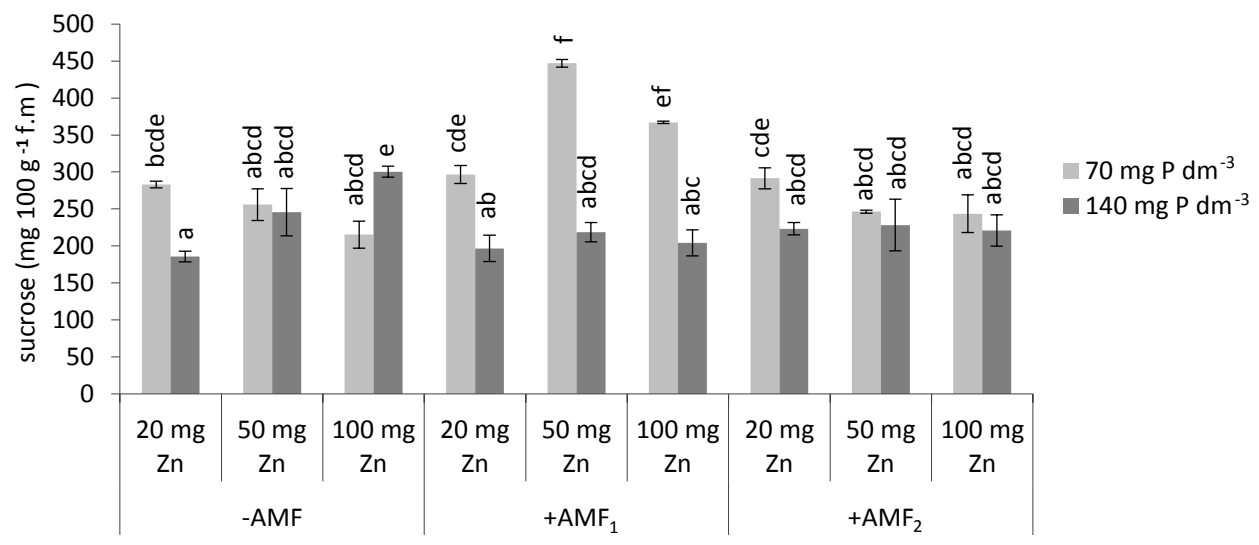

Fig. 1. Interaction among the level of $\mathrm{P}$, the level of $\mathrm{Zn}$ in the substrate and inoculation of the substrate with AMF on the content of sucrose in lettuce (mg $100 \mathrm{~g}^{-1} \mathrm{f} . \mathrm{m}$.). $-\mathrm{AMF}=$ uninoculated plants, $+\mathrm{AMF}_{1}=$ plants inoculated with Funneliformis mosseae, $+\mathrm{AMF}_{2}=$ plants inoculated with Rizophagus intraradices; $20 \mathrm{mg} \mathrm{Zn,} 50 \mathrm{mg} \mathrm{Zn,} 100 \mathrm{mg} \mathrm{Zn=20,50,} 100$ mg Zn dm³; a,b,c, = means followed by different letters differ at $p<0.05$; bars indicate standard error of mean (SEM); f.m. = fresh matter

The effect of the experimental factors on the content of macro- and micronutrients in plants was variable. Regardless of the other experimental factors, the P concentration in the peat substrate affected the content of $\mathrm{N}$, $\mathrm{P}$ and $\mathrm{Ca}$ (Table 4). A reduced $\mathrm{P}$ concentration in the substrate decreased the $\mathrm{N}$ and $\mathrm{P}$ content in lettuce, but led to an increase in the Ca level. Except for $\mathrm{K}$, inoculation caused no significant differences in the content of macronutrients among inoculated and uninoculated plants. The content of $\mathrm{K}$ was higher in the leaves of mycorrhized plants. However, there were no significant differences between the effects of either species of AMF (Table 4). Increasing the concentration of $\mathrm{Zn}$ in the substrate led to an increased content of $\mathrm{Ca}, \mathrm{K}$ and $\mathrm{Mg}$ (Table 4). Higher concentrations of $\mathrm{Ca}$ and $\mathrm{Mg}$ were observed at 50 and $100 \mathrm{mg} \mathrm{Zn}$, whereas an increased concentration of $\mathrm{K}$ was found only at $100 \mathrm{mg} \mathrm{Zn}$.

Regardless of the other experimental factors, the contents of $\mathrm{Cu}, \mathrm{Fe}$, and $\mathrm{B}$ were influenced by the $\mathrm{P}$ concentration in the substrate (Table 5). However, these effects differed for different micronutrients. Higher contents of $\mathrm{Cu}$ and Fe were observed in lettuce grown in the substrate with a standard concentration of $\mathrm{P}$, whereas for $\mathrm{B}$, the opposite relationship was found. Inoculation with AMF affected the content of $\mathrm{Cu}$ and $\mathrm{Mn}$ (Table 5). The content of $\mathrm{Cu}$ in plants was higher in inoculated plants, irrespective of the species of AMF. Similarly, the Mn content was also higher in leaves of mycorrhized plants. However, despite this increase, the Mn content in lettuce mycorrhized with $F$. mosseae was similar to that in non-mycorrhized plants and those mycorrhized with $R$. intraradices. In general, an increasing concentration of $\mathrm{Zn}$ in the substrate caused an increase in the content of Fe and B (Table 5).

A significant interaction among three experimental factors on the content of Zn was observed (Fig. 2). Regardless of the inoculation of the substrate with AMF, the content of $\mathrm{Zn}$ in lettuce increased with an increasing concentration of $\mathrm{Zn}$ in the substrate. At 20 and $50 \mathrm{mg}$ of $\mathrm{Zn}$ in the substrate, the P concentration did not significantly affect the content of $\mathrm{Zn}$ in lettuce. However, at the highest level of $\mathrm{Zn}$, i.e., $100 \mathrm{mg} \mathrm{dm}^{-3}$, in uninoculated plants, an increased content of $\mathrm{Zn}$ was observed at a higher concentration of $\mathrm{P}$, whereas in inoculated plants, a higher concentration of $\mathrm{P}$ decreased the content of $\mathrm{Zn}$ in plants, which was particularly evident for $R$. intraradices. 
Table 4. Effect of the phosphorus (P) and zinc ( $\mathrm{Zn}$ ) level in the peat substrate and inoculation of the peat substrate with AMF on the content of macronutrients (nitrogen [N], potassium [K], calcium [Ca], magnesium [Mg]) in leaves of lettuce

\begin{tabular}{|c|c|c|c|c|c|c|c|}
\hline \multirow{2}{*}{$\mathrm{P} \mathrm{mg} \mathrm{dm^{-3 }}$} & \multirow{2}{*}{ Inoculation } & \multirow{2}{*}{$\mathrm{Zn} \mathrm{mg} \mathrm{dm}{ }^{-3}$} & $\mathrm{~N}$ & $\mathrm{P}$ & $\mathrm{K}$ & $\mathrm{Ca}$ & $\mathrm{Mg}$ \\
\hline & & & \multicolumn{5}{|c|}{$\% \mathrm{DM}$} \\
\hline \multirow[t]{9}{*}{70} & \multirow[t]{3}{*}{$-A M F$} & 20 & $2.61 \pm 0.04$ & $0.30 \pm 0.01$ & $3.10 \pm 0.06$ & $1.38 \pm 0.01$ & $0.34 \pm 0.01$ \\
\hline & & 50 & $2.48 \pm 0.08$ & $0.33 \pm 0.02$ & $3.14 \pm 0.06$ & $1.52 \pm 0.04$ & $0.41 \pm 0.01$ \\
\hline & & 100 & $2.76 \pm 0.07$ & $0.35 \pm 0.02$ & $3.76 \pm 0.16$ & $1.75 \pm 0.04$ & $0.42 \pm 0.02$ \\
\hline & \multirow{3}{*}{$+\mathrm{AMF}_{1}$} & 20 & $2.50 \pm 0.08$ & $0.31 \pm 0.01$ & $3.28 \pm 0.15$ & $1.32 \pm 0.06$ & $0.30 \pm 0.01$ \\
\hline & & 50 & $2.33 \pm 0.06$ & $0.32 \pm 0.01$ & $3.16 \pm 0.04$ & $1.51 \pm 0.12$ & $0.36 \pm 0.03$ \\
\hline & & 100 & $2.57 \pm 0.09$ & $0.35 \pm 0.01$ & $3.82 \pm 0.14$ & $1.75 \pm 0.03$ & $0.40 \pm 0.01$ \\
\hline & \multirow[t]{3}{*}{$+\mathrm{AMF}_{2}$} & 20 & $2.61 \pm 0.02$ & $0.29 \pm 0.01$ & $3.34 \pm 0.06$ & $1.36 \pm 0.03$ & $0.32 \pm 0.01$ \\
\hline & & 50 & $2.48 \pm 0.15$ & $0.30 \pm 0.01$ & $3.05 \pm 0.16$ & $1.45 \pm 0.11$ & $0.33 \pm 0.02$ \\
\hline & & 100 & $2.56 \pm 0.03$ & $0.31 \pm 0.02$ & $3.85 \pm 0.16$ & $2.13 \pm 0.14$ & $0.41 \pm 0.03$ \\
\hline \multirow[t]{10}{*}{140} & \multirow[t]{3}{*}{$-\mathrm{AMF}$} & 20 & $2.75 \pm 0.08$ & $0.45 \pm 0.02$ & $3.07 \pm 0.20$ & $1.27 \pm 0.08$ & $0.36 \pm 0.03$ \\
\hline & & 50 & $2.89 \pm 0.03$ & $0.47 \pm 0.03$ & $3.29 \pm 0.23$ & $1.53 \pm 0.13$ & $0.40 \pm 0.04$ \\
\hline & & 100 & $2.55 \pm 0.08$ & $0.47 \pm 0.01$ & $3.24 \pm 0.09$ & $1.77 \pm 0.03$ & $0.39 \pm 0.01$ \\
\hline & \multirow[t]{3}{*}{$+\mathrm{AMF}_{1}$} & 20 & $2.86 \pm 0.05$ & $0.50 \pm 0.01$ & $3.58 \pm 0.05$ & $1.26 \pm 0.03$ & $0.35 \pm 0.01$ \\
\hline & & 50 & $2.61 \pm 0.06$ & $0.45 \pm 0.02$ & $3.31 \pm 0.17$ & $1.40 \pm 0.02$ & $0.37 \pm 0.02$ \\
\hline & & 100 & $2.62 \pm 0.09$ & $0.43 \pm 0.02$ & $3.68 \pm 0.27$ & $1.71 \pm 0.22$ & $0.36 \pm 0.03$ \\
\hline & \multirow[t]{4}{*}{$+\mathrm{AMF}_{2}$} & 20 & $2.62 \pm 0.03$ & $0.45 \pm 0.03$ & $3.42 \pm 0.05$ & $1.27 \pm 0.06$ & $0.34 \pm 0.01$ \\
\hline & & 50 & $2.67 \pm 0.01$ & $0.49 \pm 0.02$ & $3.73 \pm 0.05$ & $1.52 \pm 0.10$ & $0.39 \pm 0.04$ \\
\hline & & 100 & $2.63 \pm 0.04$ & $0.43 \pm 0.01$ & $3.38 \pm 0.04$ & $1.55 \pm 0.05$ & $0.37 \pm 0.01$ \\
\hline & & & \multicolumn{5}{|c|}{ Main effects } \\
\hline 70 & & & $2.54 \pm 0.03 \mathrm{a}$ & $0.32 \pm 0.01 \mathrm{a}$ & $3.39 \pm 0.07$ & $1.58 \pm 0.05 a$ & $0.36 \pm 0.01$ \\
\hline 140 & & & $2.69 \pm 0.05 b$ & $0.46 \pm 0.01 \mathrm{~b}$ & $3.41 \pm 0.06$ & $1.48 \pm 0.04 \mathrm{~b}$ & $0.37 \pm 0.01$ \\
\hline -AMF & & & $2.67 \pm 0.04$ & $0.40 \pm 0.02$ & $3.27 \pm 0.08 \mathrm{a}$ & $1.54 \pm 0.05$ & $0.39 \pm 0.01$ \\
\hline$+\mathrm{AMF}_{1}$ & & & $2.58 \pm 0.05$ & $0.39 \pm 0.02$ & $3.47 \pm 0.08 b$ & $1.49 \pm 0.06$ & $0.36 \pm 0.01$ \\
\hline$+\mathrm{AMF}_{2}$ & & & $2.60 \pm 0.03$ & $0.38 \pm 0.02$ & $3.46 \pm 0.07 b$ & $1.55 \pm 0.07$ & $0.36 \pm 0.01$ \\
\hline 20 & & & $2.66 \pm 0.03$ & $0.38 \pm 0.02$ & $3.30 \pm 0.05 a$ & $1.31 \pm 0.02 \mathrm{a}$ & $0.34 \pm 0.01 \mathrm{a}$ \\
\hline 50 & & & $2.58 \pm 0.05$ & $0.39 \pm 0.02$ & $3.28 \pm 0.07 a$ & $1.49 \pm 0.03 \mathrm{~b}$ & $0.38 \pm 0.01 \mathrm{~b}$ \\
\hline \multirow[t]{2}{*}{100} & & & $2.61 \pm 0.03$ & $0.39 \pm 0.02$ & $3.62 \pm 0.08 b$ & $1.55 \pm 0.06 \mathrm{c}$ & $0.39 \pm 0.01 \mathrm{~b}$ \\
\hline & & & \multicolumn{5}{|c|}{ ANOVA } \\
\hline $\mathrm{P}$ & & & $*$ & $*$ & n.s. & * & n.s. \\
\hline Inoculation (AMF) & & & n.s. & n.s. & $*$ & n.s. & n.s. \\
\hline $\mathrm{Zn}$ & & & n.s. & n.s. & $*$ & $*$ & $*$ \\
\hline $\mathrm{P} \times \mathrm{AMF}$ & & & n.s. & n.s. & n.s. & n.s. & n.s. \\
\hline$P \times Z n$ & & & $*$ & $*$ & $*$ & n.s. & $*$ \\
\hline AMF $x \mathrm{Zn}$ & & & n.s. & n.s. & n.s. & n.s. & n.s. \\
\hline $\mathrm{P} \times \mathrm{AMF} \times \mathrm{Zn}$ & & & n.s. & n.s. & n.s. & n.s. & n.s. \\
\hline
\end{tabular}


A. Konieczny \& I. Kowalska (2016) 25: 124-137

Table 5. Effect of the phosphorus $(\mathrm{P})$ and zinc $(\mathrm{Zn})$ level in the peat substrate and inoculation of the peat substrate with AMF on the content of micronutrients (copper [Cu], iron [Fe], boron [B], manganese [Mg], molybdenum [Mo]) in leaves of lettuce

\begin{tabular}{|c|c|c|c|c|c|c|c|}
\hline \multirow{2}{*}{$\mathrm{P} \mathrm{mg} \mathrm{dm}-3$} & \multirow{2}{*}{ Inoculation } & \multirow{2}{*}{$\mathrm{Zn} \mathrm{mg} \mathrm{dm}{ }^{-3}$} & $\mathrm{Cu}$ & $\mathrm{Fe}$ & B & $\mathrm{Mn}$ & Mo \\
\hline & & & \multicolumn{5}{|c|}{$\mathrm{mg} \mathrm{kg}^{-1} \mathrm{DM}$} \\
\hline \multirow[t]{9}{*}{70} & \multirow[t]{3}{*}{-AMF } & 20 & $3.71 \pm 0.09$ & $100.70 \pm 1.69 a b$ & $25.37 \pm 0.70$ & $186.85 \pm 6.46$ & $0.25 \pm 0.02$ \\
\hline & & 50 & $2.74 \pm 0.05$ & $107.60 \pm 6.13 \mathrm{abc}$ & $25.06 \pm 0.81$ & $162.88 \pm 6.36$ & $0.35 \pm 0.04$ \\
\hline & & 100 & $3.20 \pm 0.32$ & $121.89 \pm 3.49 \mathrm{abc}$ & $28.44 \pm 0.32$ & $174.47 \pm 2.08$ & $0.28 \pm 0.06$ \\
\hline & \multirow[t]{3}{*}{$+\mathrm{AMF}_{1}$} & 20 & $3.54 \pm 0.07$ & $85.49 \pm 2.38 \mathrm{a}$ & $23.28 \pm 0.84$ & $227.07 \pm 12.98$ & $0.31 \pm 0.05$ \\
\hline & & 50 & $3.72 \pm 0.22$ & $110.05 \pm 5.40 \mathrm{abc}$ & $25.42 \pm 1.69$ & $167.30 \pm 24.75$ & $0.33 \pm 0.09$ \\
\hline & & 100 & $4.13 \pm 0.38$ & $141.26 \pm 2.09 \mathrm{abc}$ & $26.34 \pm 0.26$ & $199.65 \pm 3.94$ & $0.36 \pm 0.05$ \\
\hline & \multirow[t]{3}{*}{$+\mathrm{AMF}_{2}$} & 20 & $3.88 \pm 0.19$ & $96.88 \pm 1.91 \mathrm{ab}$ & $23.85 \pm 0.22$ & $203.52 \pm 17.58$ & $0.32 \pm 0.04$ \\
\hline & & 50 & $3.63 \pm 0.09$ & $102.54 \pm 3.66 \mathrm{ab}$ & $23.92 \pm 1.54$ & $164.62 \pm 15.48$ & $0.21 \pm 0.01$ \\
\hline & & 100 & $3.67 \pm 0.38$ & $129.59 \pm 10.54 \mathrm{abc}$ & $26.77 \pm 1.05$ & $247.72 \pm 23.83$ & $0.24 \pm 0.02$ \\
\hline \multirow[t]{10}{*}{140} & \multirow[t]{3}{*}{$-\mathrm{AMF}$} & 20 & $4.13 \pm 0.10$ & $108.18 \pm 5.11 \mathrm{abc}$ & $22.93 \pm 1.62$ & $136.10 \pm 0.44$ & $0.37 \pm 0.05$ \\
\hline & & 50 & $3.81 \pm 0.30$ & $133.58 \pm 8.08 \mathrm{abc}$ & $26.07 \pm 1.89$ & $207.62 \pm 27.94$ & $0.28 \pm 0.03$ \\
\hline & & 100 & $4.09 \pm 0.12$ & $133.59 \pm 2.41 \mathrm{abc}$ & $24.87 \pm 0.53$ & $139.69 \pm 14.53$ & $0.31 \pm 0.10$ \\
\hline & \multirow[t]{3}{*}{$+\mathrm{AMF}_{1}$} & 20 & $4.95 \pm 0.06$ & $115.68 \pm 3.70 \mathrm{abc}$ & $23.11 \pm 0.39$ & $158.94 \pm 13.61$ & $0.19 \pm 0.01$ \\
\hline & & 50 & $4.12 \pm 0.60$ & $113.16 \pm .4 .33 \mathrm{abc}$ & $23.88 \pm 0.31$ & $211.43 \pm 26.04$ & $0.23 \pm 0.03$ \\
\hline & & 100 & $4.33 \pm 0.25$ & $116.07 \pm 8.03 \mathrm{abc}$ & $25.06 \pm 1.28$ & $196.10 \pm 33.23$ & $0.25 \pm 0.04$ \\
\hline & \multirow[t]{4}{*}{$+\mathrm{AMF}_{2}$} & 20 & $4.42 \pm 0.35$ & $113.38 \pm 5.67 \mathrm{abc}$ & $22.16 \pm 0.99$ & $190.30 \pm 15.83$ & $0.24 \pm 0.01$ \\
\hline & & 50 & $4.46 \pm 0.33$ & $131.46 \pm 21.09 a b c$ & $24.32 \pm 0.96$ & $336.04 \pm 77.22$ & $0.43 \pm 0.10$ \\
\hline & & 100 & $4.38 \pm 0.29$ & $130.80 \pm 2.76 \mathrm{abc}$ & $23.42 \pm 0.43$ & $165.50 \pm 6.76$ & $0.19 \pm 0.01$ \\
\hline & & & \multicolumn{5}{|c|}{ Main effects } \\
\hline 70 & & & $3.58 \pm 0.10 \mathrm{a}$ & $110.67 \pm 3.50 \mathrm{a}$ & $25.38 \pm 0.40 \mathrm{~b}$ & $192.68 \pm 6.87$ & $0.29 \pm 0.02$ \\
\hline 140 & & & $4.30 \pm 0.10 \mathrm{~b}$ & $121.77 \pm 3.07 b$ & $23.98 \pm 0.37 \mathrm{a}$ & $193.53 \pm 14.25$ & $0.28 \pm 0.02$ \\
\hline -AMF & & & $3.61 \pm 0.14 \mathrm{a}$ & $117.59 \pm 3.57$ & $25.46 \pm 0.56$ & $167.93 \pm 7.64 \mathrm{a}$ & $0.31 \pm 0.02$ \\
\hline$+\mathrm{AMF}_{1}$ & & & $4.13 \pm 0.16 b$ & $113.62 \pm 4.26$ & $24.52 \pm 0.44$ & $193.42 \pm 9.36 \mathrm{ab}$ & $0.28 \pm 0.02$ \\
\hline$+\mathrm{AMF}_{2}$ & & & $4.07 \pm 0.13 \mathrm{~b}$ & $117.44 \pm 4.86$ & $24.07 \pm 0.47$ & $217.95 \pm 18.82 \mathrm{~b}$ & $0.27 \pm 0.03$ \\
\hline 20 & & & $4.10 \pm 0.13$ & $103.39 \pm 2.86 a$ & $23.45 \pm 0.40 \mathrm{a}$ & $183.80 \pm 8.35$ & $0.28 \pm 0.02$ \\
\hline 50 & & & $3.74 \pm 0.17$ & $116.40 \pm 4.49 \mathrm{~b}$ & $24.78 \pm 0.49 a b$ & $208.31 \pm 19.46$ & $0.30 \pm 0.03$ \\
\hline \multirow[t]{2}{*}{100} & & & $3.97 \pm 0.11$ & $128.86 \pm 2.81 \mathrm{c}$ & $25.82 \pm 0.46 \mathrm{~b}$ & $187.19 \pm 10.23$ & $0.27 \pm 0.02$ \\
\hline & & & \multicolumn{5}{|c|}{ ANOVA } \\
\hline $\mathrm{P}$ & & & * & $*$ & * & n.s. & n.s. \\
\hline $\begin{array}{c}\text { Inoculation } \\
\text { (AMF) }\end{array}$ & & & $*$ & n.s. & n.s. & $*$ & n.s. \\
\hline $\mathrm{Zn}$ & & & n.s. & $*$ & $*$ & n.s. & n.s. \\
\hline $\mathrm{P} \times \mathrm{AMF}$ & & & n.s. & n.s. & n.s. & n.s & n.s. \\
\hline$P \times Z n$ & & & n.s. & $*$ & n.s. & n.s & n.s. \\
\hline $\mathrm{AMF} \times \mathrm{Zn}$ & & & n.s. & n.s. & n.s. & n.s. & n.s. \\
\hline P x AMF x Zn & & & n.s. & $*$ & n.s. & n.s & n.s. \\
\hline
\end{tabular}

$*=$ means are significantly different; $n . s .=$ differences are not significant; $\pm=$ standard error of mean $(S E M) ; a, b, c=$ means followed by different letters differ at $p<0.05$; $-\mathrm{AMF}=$ uninoculated plants with arbuscular mycorrhizal fungi, $+\mathrm{AMF}_{1}=$ plants inoculated with Funneliformis mosseae; $+\mathrm{AMF}_{2}=$ plants inoculated with Rhizophagus intraradices; $\mathrm{DM}=$ dry matter

Besides, the significant interaction between the $\mathrm{Zn}$ concentration in the substrate and inoculation with AMF on the $\mathrm{Zn}$ content in lettuce (Fig. 3) showed that the increase of $\mathrm{Zn}$ content in lettuce was the greatest in plants grown at $100 \mathrm{mg} \mathrm{Zn}$ in the substrate and inoculated with $R$. intraradices. 


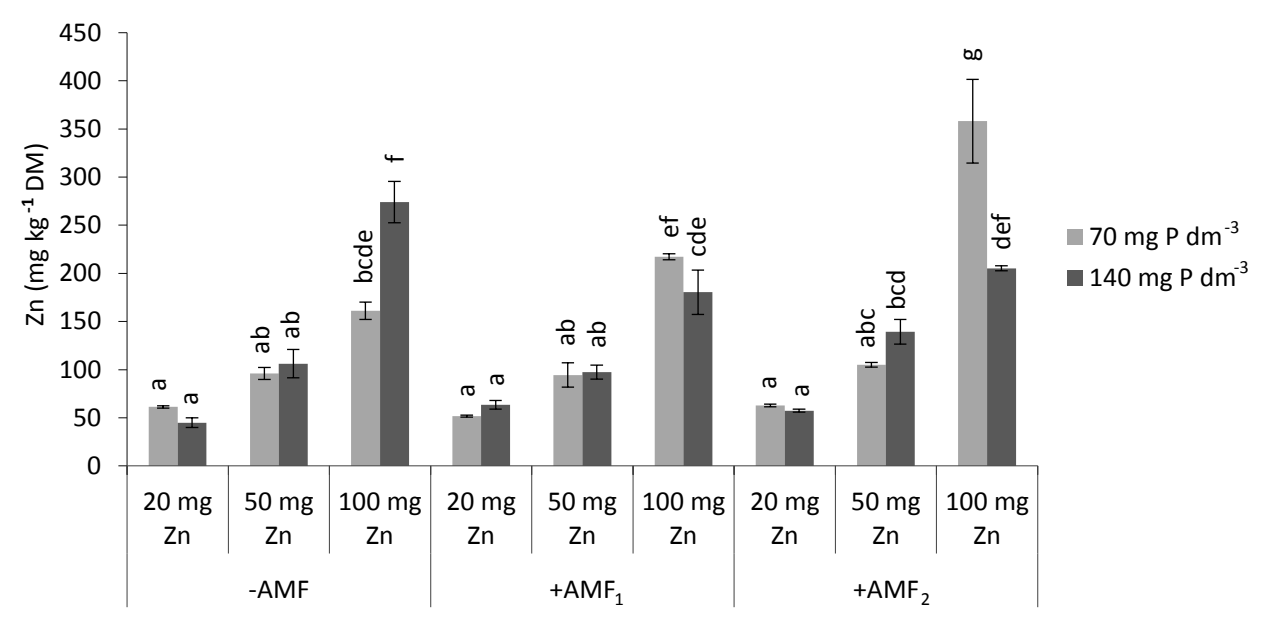

Fig. 2. Interaction among the level of $P$, the level of $Z n$ in the substrate and inoculation of the substrate with $A M F$ on the content of $Z n$ in lettuce $\left(\mathrm{mg} \mathrm{kg}^{-1} \mathrm{DM}\right) .-\mathrm{AMF}=$ uninoculated plants, $+\mathrm{AMF}_{1}=$ plants inoculated with Funneliformis mosseae, $+\mathrm{AMF}_{2}=$ plants inoculated with Rizophagus intraradices; $20 \mathrm{mg} \mathrm{Zn,} 50 \mathrm{mg} \mathrm{Zn,} 100 \mathrm{mg} \mathrm{Zn}=20,50,100 \mathrm{mg} \mathrm{Zn} \mathrm{dm}^{-3} ; \mathrm{a}, \mathrm{b}, \mathrm{c}$, = means followed by different letters differ at $p<0.05$; bars indicate standard error of mean (SEM); DM = dry matter

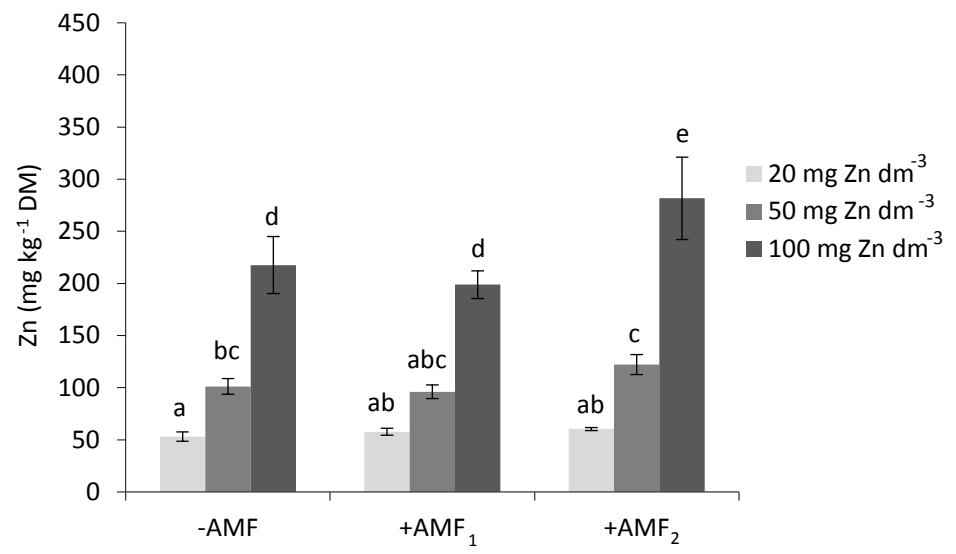

Fig. 3. Interaction between the level of $\mathrm{Zn}$ in the substrate and inoculation of the substrate with $A M F$ on content of $\mathrm{Zn}$ in lettuce $\left(\mathrm{mg} \mathrm{kg}^{-1} \mathrm{DM}\right) .-\mathrm{AMF}=$ uninoculated plants; $+\mathrm{AMF}_{1}=$ plants inoculated with Funneliformis mosseae; $+\mathrm{AMF}_{2}=$ plants inoculated with Rhizophagus intraradices; $\mathrm{a}, \mathrm{b}, \mathrm{c}=$ means followed by different letters differ at $p<0.05$; bars indicate standard error of mean (SEM); DM = dry matter

\section{Discussion}

The degree of the AMF colonisation of lettuce roots (23.81 and $20.40 \%$, for $+\mathrm{AMF}_{1}$ and $+\mathrm{AMF}_{2}$ plants respectively) was lower than that described by Baslam et al. (2011), who cultivated lettuce in a mixture of vermiculite, sand and peat. Colonisation by AMF in their experiment ranged from 56 to $61 \%$ in roots of plants inoculated with a mixture of F. mosseae (G. mosseae) and R. intraradices (G. intraradices) and was about $65 \%$ in plants inoculated with $R$. fasciculatus ( $G$. fasciculatum). The reason for this difference is probably connected with properties of used growing medium. Although, peat because of its physical and chemical properties seems to be suitable substrate for the development of AMF, the addition of mineral compounds could create better conditions for AMF development. Vestberg and Kukkonen (2007) proved that light Sphagnum peat clearly suppressed the function of AMF, resulting in low colonization level of plant roots. However, the functioning of AMF was improved in peat mixtures with clay or pumice. Linderman and Davis (2003) suggested that peats are not equal in physical, chemical and biological properties, what can suppress or enhance mycorrhizal colonization. Additionally, these effects may also be connected with species of mycorrhizal fungus. We also suppose that cultivation period of lettuce in sterile growing media, is too short for high development of mycorrhizal structures. Sterile growing media in contrast to soil are devoid of the presence of AMF and inoculum is introducing at the time of planting. 
Despite the low mycorrhizal colonisation, an effect of mycorrhiza on the yield and some quality parameters was observed. Among the fungi used in the experiment, F. mosseae (+AMF ${ }_{1}$ ) affected lettuce yield. Plants inoculated with this fungus showed the highest weight of a head. It is known that AMF lead to an increase in plant growth (Aguilera-Gomez et al. 1999). This beneficial effect is often associated with an enhancement of $P$ uptake and better plant P status (Wu and Zou 2010). However, an increased P uptake by inoculated plants was not observed in this experiment, therefore, a higher weight of lettuce head was probably due to a different mechanism. According to Barea and Azcón-Aguilar (1982), mycorrhizal benefits might not be limited to improved nutrient uptake and the production of plant hormones by these mutualistic fungi might also be involved in their effects on plant metabolic processes. Funneliformis mosseae (G. mosseae) synthesised at least two gibberellin-like substances and four substances with the properties of cytokinins (Barea and Azcón-Aguilar 1982). Allen et al. (1980) demonstrated that mycorrhizal infection increased the content of cytokinins in host plants. Since there was no effect of the mycorrhiza on the $\mathrm{P}$ status of plants in this experiment, it is possible that a higher head weight of lettuces inoculated with F. mosseae might relate to the plant growth-regulating hormones discussed. Another possible explantation of higher weight of lettuce inoculated with F. mosseae may be connected with a higher amount of water in plant tissues (Marulanda et al. 2003).

In our experiment at $70 \mathrm{mg}$ of $\mathrm{P}$ and higher doses of $\mathrm{Zn}(50$ and $100 \mathrm{mg}$ ) in substrate we observed the increased content of sucrose in plants inoculated with F. mosseae. The higher content of sucrose at lower P content in the substrate might be connected with slightly better development of mycorriza. The increase of the content of sugars in the presence of AMF agrees with the findings of Baslam et al. (2011), who observed an enhanced level of total soluble sugars in the inner leaves of two types of lettuce inoculated with a mixture of $F$. mosseae (G. mosseae) and $R$. intraradices ( $G$. intraradices). This increased accumulation of total soluble sugars might be associated with an enhancement of photosynthesis in inoculated plants, since the beneficial effect of AMF on the photosynthetic rate has been demonstrated in several experiments (Wu and Zou 2010, Zhu et al. 2014). It can also be assumed that the increased rate of photosynthesis in plants inoculated with $F$. mosseae might also have increased the weight of lettuce heads in this experiment. The increase of these parameters was slight but statistically significant.

Plant symbiosis with AMF can be influenced by many factors, including the P content in the root zone (Smith and Read 2008). It has been widely reported that a high concentration of $P$ in the root zone reduces the colonisation of roots by AMF (Schmidt et al. 2010, Kowalska et al. 2015). The negative effect of a higher P concentration in the substrate $\left(140 \mathrm{mg} \mathrm{dm}^{-3}\right)$ on the development of mycorrhizal structures was also found in this experiment, compared with plants grown in conditions of $P$ deficiency $\left(70 \mathrm{mg} \mathrm{dm}^{-3}\right)$. The reason for the limiting effect of high $\mathrm{P}$ doses on root colonisation by AMF is unclear. Amijee et al. (1989) cultivated leak plants at standard and elevated $P$ concentrations and found large changes in the extension rate, infection delay and infection density, which might be due to the marked change in plant and fungal physiology. An important role of strigolactones as signaling molecules in the stimulation of spore germination and the development of extraradical mycelium has been suggested (Akiyama et al. 2005, Besserer et al. 2006). The exudation of these molecules by plant roots is promoted under conditions of $\mathrm{P}$ and $\mathrm{N}$ deficiency in the root zone. Optimal or increased concentrations of $\mathrm{P}$ and $\mathrm{N}$ reduce the exudation of strigolactones (Yoneyama et al. 2012), which might limit the growth of mycelium and decrease the probability of contact with the host plant.

The scientific hypothesis of the present study was that AMF inoculation limits Zn uptake by the plants, when Zn concentration in the medium is high and close to toxic levels. However, no effect of AMF on reducing $\mathrm{Zn}$ uptake in lettuce grown in a high concentration of $\mathrm{Zn}$ in the substrate was demonstrated. Generally, regardless of inoculation with $A M F$, the $Z n$ concentration in lettuce increased with an increasing concentration of $Z n$ in the substrate. The highest $\mathrm{Zn}$ concentration was found in plants grown at $70 \mathrm{mg}$ of $\mathrm{P}, 100 \mathrm{mg} \mathrm{Zn}$ and surprisingly, in plants that were inoculated with $R$. intraradices (Fig. 2). Kozik et. al (2009) also observed the increased Zn content in lettuce with increasing content of $\mathrm{Zn}$ in the substrate. In their experiment content of $\mathrm{Zn}$ in lettuce ranged between 128.6 and $291.1 \mathrm{mg} \mathrm{kg}^{-1}$ dry matter. In our experiment content of $\mathrm{Zn}$ in lettuce grown at optimal $\mathrm{Zn}$ dose in the substrate ranged between 44.90 and $63.50 \mathrm{mg} \mathrm{kg}^{-1}$ dry matter, which is in a range considered as optimal for lettuce i.e. 39-71 mg kg-1 dry matter (Benton Storey 2007). The contents of $\mathrm{Zn}$ in lettuce grown at 50 and $100 \mathrm{mg}$ of $\mathrm{Zn}$ in the substrate were 96.06-139.26 and 161.18-358.12 $\mathrm{mg} \mathrm{kg}^{-1}$ dry matter. Despite that, these values exceeded the optimal content of $\mathrm{Zn}$ in lettuce we did not observe the symptoms of its toxicity on plants. This suggests the high tolerance of lettuce to high $\mathrm{Zn}$ concentration in the root zone.

It has been widely reported that inoculation with AMF enhances nutrient uptake by plants, including that of $\mathrm{P}$ and Zn (Thompson et al. 2013, Lehmann et al. 2014), but in conditions of high soil Zn concentration, AMF can reduce Zn accumulation in the aboveground parts of plant (Li and Christie 2001, Zhu et al. 2001). Zhu et al. (2001) found that increasing dose of $\mathrm{Zn}$ in the medium in a glasshouse pot experiment with white clover led to an increased 
uptake of $\mathrm{Zn}$, but this increase was greater in non-mycorrhizal than in mycorrhizal plants. A similar relationship was demonstrated by Li and Christie (2001) in red clover grown at four levels of $\mathrm{Zn}$ in the soil. In an experiment with tomato grown at two levels of $Z n$ in the soil, i.e., low and high, Watts-Williams et al. (2013) found that mycorrhizal plants accumulated more $\mathrm{Zn}$ when it was deficient in the soil $\left(0.13 \mathrm{mg} \mathrm{kg}^{-1}\right)$ and accumulated much less when the $\mathrm{Zn}$ content in the soil was at a toxic level $\left(85.6 \mathrm{mg} \mathrm{kg}^{-1}\right)$.

The mechanism that limits the uptake, translocation and accumulation of $\mathrm{Zn}$ by AMF in plants grown in high and toxic $\mathrm{Zn}$ conditions is unclear, but is probably different from the mechanism which improves $\mathrm{Zn}$ uptake under conditions of Zn deficiency (Smith and Read 2008). The protective effect of AMF might result from Zn immobilisation in the fungal mycelium (Chen et al. 2003), which possesses a very strong metal-binding capacity (Joner et al. 2000). This effect might also be associated with changes in Zn solubility, which is affected by the $\mathrm{pH}$ in the plant root zone (Li and Christie 2001). An improvement in plant $\mathrm{P}$ nutrition by AMF, which allows plants to alleviate the negative effect of $\mathrm{Zn}$ (Shetty et al. 1995), might also be involved.

As mentioned above, the limiting effect of AMF on $\mathrm{Zn}$ uptake by lettuce was not observed in the present experiment; it is possible that the $\mathrm{Zn}$ dose used was too low to activate the mechanism that limits $\mathrm{Zn}$ uptake by inoculated plants. Moreover, the highest dose cannot be regarded as toxic, since no typical Zn toxicity symptoms on plants were observed, such as leaf chlorosis, browning or drying of the leaf blade or the stunting and dying of plants (Sagardoy et al. 2009).

Increased doses of Zn slightly but significantly decreased the yield of lettuce, although the yield of plants grown on 50 or $100 \mathrm{mg}$ of Zn substrate was similar. This weak effect of Zn dose on the yield of lettuce was independent of inoculation by AMF, confirming that even the highest dose of $Z n$ was not detrimental to the plants. We expected that the highest dose would reduce the yield in -AMF plants and induce the protective mechanism of the AMF in +AMF plants, but this was not the case. Chen et al. (2003) demonstrated that in the presence of AMF, a critical $\mathrm{Zn}$ concentration exists, below which uptake of $\mathrm{Zn}$ was enhanced, whereas above this level, $\mathrm{Zn}$ translocation to the shoots decreased. Authors in their experiment with red clover grown at four $\mathrm{Zn}$ addition levels in soil $(0,50$, 100 and $300 \mathrm{mg} \mathrm{kg}^{-1}$ ) found that, compared to un inoculated plants, AMF increased Zn content in plants grown at 0 and $50 \mathrm{mg}$ and decreased at 100 and $300 \mathrm{mg}$ of $\mathrm{Zn}$. According to Christie et al. (2004), this critical value might differ between different soil types and plant species. Kozik et al. (2009) in experiment with lettuce grown at four $\mathrm{Zn}$ levels in peat substrate i.e. 10, 20,30, $60 \mathrm{mg} \mathrm{dm}^{-3}$ found the decrease of the yield with increasing $\mathrm{Zn}$ content, however the differences were not statistically significant. Authors did not observe the symptoms of $\mathrm{Zn}$ toxicity on plants. In our experiment, the symptoms of Zn toxicity were also not observed, but 50 and $100 \mathrm{mg}$ doses of $\mathrm{Zn}$ caused slight but significant reduction of the yield.

A lower $\mathrm{Zn}$ concentration in lettuce leaves was observed in plants inoculated with $F$. mosseae than in plants inoculated with $R$. intraradices, both grown at $70 \mathrm{mg}$ of $\mathrm{P}$ and $100 \mathrm{mg}$ of $\mathrm{Zn}$ in the $\mathrm{dm}^{-3}$ of substrate. Lingua et al. (2008) demonstrated a differential response of two poplar varieties on a high soil Zn concentration when the plants were inoculated with F. mosseae (G. mosseae) or R. intraradices ( $G$. intraradices). Funneliformis mosseae (G. mosseae) slightly, but significantly, reduced the Zn accumulation in the leaves of one poplar variety, compared to uninoculated plants, whereas $R$. intraradices ( $G$. intraradices) did not affect the $\mathrm{Zn}$ content of poplar plants. Therefore, AMF can alleviate the stress induced by high Zn concentrations in the plant root zone, but this response depends upon both the fungus and plant species.

Generally, a beneficial effect of AMF on the uptake of some nutrients, i.e., $\mathrm{K}, \mathrm{Cu}, \mathrm{Mn}$ and $\mathrm{Zn}$ was observed in this experiment. It is known that by increasing the absorption surface of plant root system, AMF colonisation enhances the uptake of nutrients (Smith and Read 2008). This effect was observed in this experiment, despite a low relative abundance of arbuscules, which was 0.01 and $0.18 \%$, for $+\mathrm{AMF}_{1}$ and $+\mathrm{AMF}_{2}$, respectively. Arbuscules are bushy branched ends of AMF hyphae, which are located within plant root cells and are involved in the exchange of metabolites between a plant and the fungus (Parniske 2008). It is difficult to explain why AMF colonisation improved the plant nutritional status in $\mathrm{K}, \mathrm{Cu}, \mathrm{Mn}$ and $\mathrm{Zn}$, despite the low relative abundance of arbuscules obtained in our experiment. Both $R$. intraradices and F. mosseae affected the content $\mathrm{K}, \mathrm{Cu}$ and $\mathrm{Mn}$ to a similar extent. However, only $R$. intraradices increased the $\mathrm{Zn}$ content in lettuce. The reason for these differences between both fungi in Zn uptake by plants remains unclear. Limited Zn uptake in plants inoculated with $F$. mosseae might be linked with the protective effect of this fungus. Further studies are needed to estimate the critical concentration below which Zn uptake is enhanced, or above which it is limited, considering the characteristics of particular fungi. Moreover, the effect of AMF on nutritional status and metabolism of lettuce may also be affected by a cultivar of lettuce as well as the season of cultivation (Baslam et al. 2013). 
The uptake of $\mathrm{Zn}$ by plants can also be influenced by the interaction of $\mathrm{Zn}$ with other nutrients in the soil, especially $\mathrm{P}$ (Christie et al. 2004, Benton Storey 2007). Moreover, this interaction is even more complicated when the effect of AMF is superimposed (Li and Christie 2001). Shetty et al. (1995) assumed that P and Zn are mutually antagonistic when either element exceeds a threshold value. In our experiment, we found no interaction between the $\mathrm{P}$ and $\mathrm{Zn}$ concentration on their uptake by plants. The $\mathrm{P}$ level in the substrate did not affect the content of $\mathrm{Zn}$ in lettuce and moreover, the $\mathrm{Zn}$ level in the substrate had no effect on the $\mathrm{P}$ content of lettuce. This might be linked with the $\mathrm{Zn}$ dose used in the experiment, which was not high enough to reveal the antagonism between $\mathrm{P}$ and $\mathrm{Zn}$ or with the effect of the peat sorption complex on reducing contact between these two nutrients.

In conclusion, no effect of AMF on the reduction of $\mathrm{Zn}$ uptake in lettuce grown at a high concentration of $\mathrm{Zn}$ in the substrate was demonstrated. The reason is probably that the $\mathrm{Zn}$ dose was too low to be toxic to lettuce and did not activate the mechanism that limits $\mathrm{Zn}$ uptake by inoculated plants. Moreover, two AMF differentially affected the $\mathrm{Zn}$ content in lettuce. In relation to the uninoculated plants, $R$. intraradices increased the $\mathrm{Zn}$ content in lettuce, whereas F. mosseae did not affect the content. Further studies are needed to estimate whether the $\mathrm{Zn}$ concentration in the root zone below which $\mathrm{Zn}$ uptake is enhanced and above which it is limited, is a characteristic of the plant or fungal species, as well as the type of soil.

\section{Acknowledgements}

The work was financially supported by the grant for scientific research no. 3500, approved by the Polish Ministry of Science and Higher Education.

\section{References}

Aguilera-Gomez, L., Davies, F.T.Jr., Olalde-Portugal, V., Duray, S.A. \& Phavaphutanon, L. 1999. Influence of phosphorus and endomycorrhiza (Glomus intraradices) on gas exchange and plant growth on chile ancho pepper (Capsicum annuum L. cv. San Luis). Photosynthetica 36: 441-449.

Allen, F., Moore, T.S. \& Christensen, M. 1980. Phytohormone changes in Bouteloua gracilis infected by vesicular-arbuscular mycorrhizae: I. Cytokinin increases in the host plant. Canadian Journal of Botany 58: 371-374.

Amijee, F., Tinker, P.B. \& Stribley, D.P. 1989. The development of endomycorrhizal root systems. VII: a detailed study of effects of soil phosphorus on root colonization. New Phytologist 111: 435-446.

Akiyama, K., Matsuzaki, K. \& Hayashi, H. 2005. Plant sesquiterpenes induce hyphal branching in arbuscular mycorrhizal fungi. Nature 435: 824-827.

Barea, J.M. \& Azcón-Aguilar, C. 1982. Production of plant growth-regulating substances by the vesicular-arbuscular mycorrhizal fungus Glomus mosseae. Applied and Environmental Microbiology 43: 810-813.

Baslam, M., Garmendia, I. \& Goicoechea, N. 2011. Arbuscular mycorrhizal fungi (AMF) improved growth and nutritional quality of greenhouse-grown lettuce. Journal of Agricultural and Food Chemistry 59: 5504-5515.

Baslam, M., Garmendia, I. \& Goicoechea, N. 2013. The arbuscular mycorrhizal symbiosis can overcome reductions in yield and nutritional quality in greenhouse-lettuces cultivated at inappropriate growing seasons. Scientia Horticulturae 164: 145-154.

Benton Storey, J. 2007. Zinc. In: Barker, A.V. \& Pilbeam, J.D. (eds.). Handbook of plant nutrition. Boca Raton: Taylor \& Francis Group. p. 411-436.

Besserer, A., Puech-Pagès, V., Kiefer, P., Gomez-Roldan, V., Jauneau, A., Roy, S., Portais, J-Ch., Roux, C., Bécard, G. \& Séjalon-Delmas, N. 2006. Strigolactones stimulate arbuscular mycorrhizal fungi by activating mitochondria. PLoS Biology 4: 1239-1247.

Chaney, R.L. 1993. Zinc phytotoxicity. In: Robson, A.D. (ed.). Zinc in soils and plants. Dordrecht: Kluwer Academic Publishers. p. 135-150.

Chen, B.D., Li, X.L., Tao, H.Q., Christie, P. \& Wong, M.H. 2003. The role of arbuscular mycorrhiza in zinc uptake by red clover growing in calcareous soil spiked with various quantities of zinc. Chemosphere 50: 839-846.

Christie, P., Li, X. \& Chen, B. 2004. Arbuscular mycorrhiza can depress translocation of zinc to shoots of host plants in soils moderately polluted with zinc. Plant and Soil 261: 209-217.

Joner, E.J., Briones, R. \& Leyval, C. 2000. Metal binding capacity of arbuscular mycorrhizal mycelium. Plant and Soil 226: 227-234.

Kabata-Pendias A. 2011. Trace elements in soils and plants. 4th ed. Boca Raton: Taylor \& Francis Group. p. 275-287.

Karagiannidis, N., Nikolaou, N., Ipsilantis, I. \& Zioziou, E. 2007. Effects of different N fertilizers on the activity of Glomus mosseae and on grapewine nutrition and berry composition. Mycorrhiza 18: 43-50.

Karandashov, V. \& Bucher, M. 2005. Symbiothic phosphate transport in arbuscular mycorrhizas. Trends in Plant Science 10: 22-29.

Kowalska, I., Konieczny, A., Gąstoł, M., Sady, W. \& Hanus-Fajerska, E. 2015. Effect of mycorrhiza and phosphorus content in nutrient solution on the yield and nutritional status of tomato plants grown on rockwool or coconut coir. Agricultural and Food Science 24: 39-51.

Kozik, E., Tyksiński, W. \& Komosa, A. 2009. Effect of chelated and mineral forms of micronutrients on their content in leaves and the yield of lettuce. Part III, Zinc. Acta Scientarum Polonorum, Hortorum Cultus 8: 37-43. 
Lehmann, A., Veresoglou, S.D., Leifheit, E.F. \& Rillig, M.C. 2014. Arbuscular mycorrhizal influence on zinc nutrition in crop plants - A meta-analysis. Soil Biology \& Biochemistry 69: 123-131.

$\mathrm{Li}, \mathrm{X}$. \& Christie, P. 2001. Changes in soil solution $\mathrm{Zn}$ and $\mathrm{pH}$ and uptake of $\mathrm{Zn}$ by arbuscular mycorrhizal red clover in $\mathrm{Zn}$-contaminated soil. Chemosphere 42: 201-207.

Linderman, R.G. \& Davis, E.A. 2003. Soil amendment with different peatmosses affects mycorrhizae of onion. HortTechnology 13: $285-289$.

Lingua, G., Franchin, C., Todeschini, F., Castiglione, S., Biondi, S., Burlando, B., Parravicini, V., Torrigiani, P. \& Berta, G. 2008. Arbuscular mycorrhizal fungi differentially affect the response to high zinc concentrations of two registered poplar clones. Environmental Pollution 153: 137-147.

Marulanda, A., Azcón, R. \& Ruiz-Lozano, J.M. 2003. Contribution of six arbuscular mycorrhizal fungal isolates to water uptake by Lactuca sativa plants under drought stress. Physiologia Plantarum 119: 526-533.

Nicolle, C., Cardinault, N., Gueux, E., Jaffrelo, L., Rock. E., Mazur, A., Amoroux, P. \& Rémésy, Ch. 2004. Health effect of vegetable-based diet: Lettuce consumption improves cholesterol metabolism and antioxidant status in the rat. Clinical Nutrition 23: 605-614.

Parniske, M . 2008. Arbuscular mycorrhiza: the mother of plant root endosymbioses. Nature Revievs Microbiology 6: 763-775.

Pasławski, P. \& Migaszewski, Z.M. 2006. The quality of element determinations in plant material by instrumental methods. Polish Journal of Environmental Studies 15: 154-164.

Persson, J.A. \& Wennerholm, M. 1999. Poradnik mineralizacji Kjeldahl'a. Warszawa: Labconsult. (in Polish).

Phillips, J.M \& Hayman, D.S. 1970. Improved procedures for clearing roots and staining parasitic and vesicular-arbuscular mycorrhizal fungi for rapid assessment of infection. Transaction of British Mycological Society 55: 158-161.

Rosen, J.A., Pike, C.S., Golden, M.L. \& Freedman J. 1978. Zinc toxicity in corn as a result of a geochemical anomaly. Plant and Soil 50: 151-159.

Ruiz-Lozano, J.M., Aroca, R., Zamarreño, Á.M., Molina, S., Andreo-Jiménez, B., Porcel, R., García-Mina, J.M., Ruyter-Spira, C. \& López-Ráez, J.A. 2016. Arbuscular mycorrhizal symbiosis induces strigolactone biosynthesis under drought and improves drought tolerance in lettuce and tomato. Plant Cell \& Environment 39: 441-452.

Sagardoy, R., Morales, F., López-Millan, A.F., Abadia, A. \& Abadia, J. 2009. Effects of zinc toxicity on sugar beet (Beta vulgaris L.) plants grown in hydroponics. Plant Biology 11: 339-350.

Scokart, P.O., Meeus-Verdinne, K. \& De Borger, R. 1983. Mobility of heavy metals in polluted soil near zinc smelters. Water Air \& Soil Pollution 20: 451-463.

Schmidt, B., Domonkos, M., Sumalan, R. \& Biro, B. 2010. Suppression of arbuscular mycorrhiza's development by high concentrations of phosphorus at Tagetes patula L. Research Journal of Agricultural Science 42: 156-162.

Shetty, K.G., Hetrick, B.A.D. \& Schwab, A.P. 1995. Effects of mycorrhizae and fertilizer amendments on zinc tolerance of plants. Environmental Pollution 88: 307-314.

Smical, A-I., Hotea, V., Oros, V., Juhasz, J. \& Pop, E. 2008. Studies on transfer and bioaccumulation of heavy metals from soil into lettuce. Environmental Engineering and Management Journal 7: 609-615.

Smith, S.E. \& Read, D.J. 2008. Mycorrhizal symbiosis. 3rd ed. London: Elsevier LTD. p. 13-187.

Thompson, J.P., Clewett, T.G. \& Fiske, M.L. 2013. Field inoculation with arbuscular-mycorrhizal fungi overcomes phosphorus and zinc deficiencies of linseed (Linum usitatissimum in a vertisol subject to long-fallow disorder. Plant and Soil 371: 117-137.

Trouvelot, A., Kough, J.L. \& Gianinazzi-Pearson V. 1986. Mesure du taux de mycorrhization VA d'un systeme radiculaire. Recherche de methods d'estimation ayant une signification fonctionnelle. In: Gianinazzi-Pearson, V. \& Gianinazzi, S. (eds.). Physiological and genetical aspects of mycorrhizae. Paris: INRA. p. 217-221.

Turnau, K., Jurkiewicz, A. \& Grzybowska, B. 2002. Rola mikoryzy w bioremediacji terenów zanieczyszczonych. Kosmos, Problemy Nauk Biologicznych 51: 185-194. (in Polish).

Watts-Williams, S.J., Patti, A.F. \& Cavagnaro, T.R. 2013. Arbuscular mycorrhizas are beneficial under both deficient and toxic soil zinc condition. Plant and Soil 371: 299-312.

Wu, Q.S. \& Zou, Y.N. 2010. Beneficial role of arbuscular mycorrhizas in citrus seedlings at temperature stress. Scientia Horticulturae 125: 289-293.

Vestberg, M. \& Kukkonen, S. 2007. Microbiologically improved peat-based media for nursery production by addition of arbuscular mycorrhizal fungi. Acta Horticulturae 819: 403-410.

Vincente-Sánches, J., Nicolás, E., Pedrero, F., Alarcón, J.J., Maestre-Valero, J.F. \& Fernández F. 2014. Arbuscular mycorrhizal symbiosis alleviates detrimental effects of saline reclaimed water in lettuce plants. Mycorrhiza 24: 339-348.

Yoneyama, K., Xie, X., Kim, H.I., Kisugi, T., Nomura, T., Sekimoto, H., Yokota, T. \& Yoneyama K. 2012. How do nitrogen and phosphorus deficiencies affect strigolactone production and exudation? Planta 235: 1197-1207.

Zhao, Y.Q., Zheng, J.P., Yang, M.W., Yang, G.D., Wu, Y.N. \& Fu F.F. 2011. Speciation analysis of selenium in rice samples by using capillary electrophoresis-inductively coupled plasma mass spectrometry. Talanta 84: 983-988.

Zhu, Y.G., Christie, P. \& Laidlaw, S.A. 2001. Uptake of Zn by arbuscular mycorrhizal white clover from Zn-contaminated soil. Chemosphere 42: 193-199.

Zhu, X.Q., Wang, C.Y., Chen, H. \& Tang, M. 2014. Effects of arbuscular mycorrhizal fungi on photosynthesis, carbon content and calorific value of black locust seedlings. Photosynthetica 52: 247-252. 